\title{
THE ANEMIA OF INFECTION. I. HYPOFERREMIA, HYPERCU- PREMIA, AND ALTERATIONS IN PORPHYRIN METABOLISM IN PATIENTS 1
}

\author{
By G. E. CARTWRIGHT, M. A. LAURITSEN, P. J. JONES, I. M. MERRILL, \\ AND M. M. WINTROBE \\ (From the Department of Medicine, University of Utah School of Medicine, Salt Lake City)
}

(Received for publication July 7, 1945)

Heretofore, the anemia associated with infections has been overshadowed in importance by the difficulties of treatment of the infection. While the latter have not been solved completely, modern chemotherapy has made possible such advances that it has brought into contrast the slowness of convalescence and the refractoriness to treatment of the anemia associated with infections.

This anemia has been inadequately studied. Its nature is in dispute, the mechanism of its production is not understood, and there is available at present no rational form of treatment. $\mathrm{Re}$ lief of the infection is associated with slow blood regeneration. Whole blood transfusions have been used empirically. It has been claimed that the anemia is actually even more severe than it appears because a pronounced reduction in total blood volume occurs at the same time.

The present study was undertaken with the object of determining the pathogenesis of the anemia associated with infection since it seems apparent that successful treatment, comparable to the effectiveness of liver therapy in pernicious and related anemias and iron medication in iron deficiency anemias, is not likely to be attained until the anemia is better understood. In this paper, the literature is reviewed, and certain observations on iron, copper, and porphyrin metabolism in male subjects suffering from anemia associated with empyema, osteomyelitis, and other infections are presented. In the communication that follows experimental studies in dogs will be reported.

\footnotetext{
1 The work described in this paper was carried out under a contract, recommended by the Committee on Medical Research, between the Office of Scientific Research and Development and the University of Utah. The expenses of this investigation were also defrayed in part by grants from Parke, Davis and Company and the Upjohn Company.
}

REVIEW OF THE LITERATURE

\section{Morphological characteristics}

Information on this subject is not adequate and that which exists is not in complete agreement. The color index is generally stated to be low. In 24 cases of infective endocarditis with anemia the color index was low (1). In cases of rheumatoid arthritis (2) with anemia, the color index was reported as low. In rheumatic fever the cell size, mean corpuscular hemoglobin, and mean corpuscular hemoglobin concentration varied irregularly from low to normal values (3). A "hypochromic" type of anemia was reported in 12 per cent of 460 cases of pulmonary tuberculosis (4), and a low color index was found in infants with anemia due to sepsis (5). In 18 cases of inflammatory disease which included pneumonia, pulmonary abscess, chronic cholecystitis, chronic arthritis, and infections of the genito-urinary tract, the anemia was normocytic (6). The average mean corpuscular volume was 87 c. $\mu$., and the mean corpuscular hemoglobin concentration was 34 per cent. In 27 other cases of similar character the anemia was somewhat microcytic (M. C. V. 72 to 65 c. $\mu$.), but not hypochromic (M. C. H. C. 31 to 34 per cent). Of the total of 464 cases of anemia studied, in no instance was macrocytic or hypochromic anemia observed in association with infection uncomplicated by blood loss or nutritional deficiency. Thus, the anemia of infection was classified with the "normocytic" and the "simple microcytic" anemias (6).

In a study (7) of various acute and chronic infections such as osteomyelitis, chronic meningococcemia, cellulitis, empyema, subacute bacterial endocarditis, and chronic pyelonephrosis, the infections were divided into acute and chronic, setting the dividing line arbitrarily at 3 months. Of the acute group normocytic anemia was present in 
5 and microcytic anemia in 2 . The color index ranged from 0.53 to 0.95 but in the majority it was above 0.8 . In two-thirds of their cases the reticulocyte count was elevated during the active stage of the infection, the maximal count being 9.4 per cent. In the remaining third of the cases the reticulocyte count was normal. In the chronic cases normocytic anemia was present in 6 and microcytic anemia was evident in 4 . The color index in this group varied between 0.56 and 0.94 with an average of 0.70 . The reticulocyte count was slightly elevated in all cases showing anemia (average 4.6 per cent, maximum 7.6 per cent). No case of macrocytic anemia was found in either group.

The anemia associated with infected gunshot fractures and infected wounds has been described as macrocytic and slightly hypochromic (8). The mean corpuscular volume in 9 of 12 cases was above 94 c. $\mu$. In only one case was the mean corpuscular hemoglobin concentrated above 31 per cent. The duration of the infections ranged from 6 weeks to 3 months. In this report it was stated, "The relatively brief duration of the chronic infection may be the explanation for the absence of the microcytic hypochromic anemia usually associated with chronic infection." The reference to microcytic hypochromic anemia as the usual finding is not borne out by the literature (9). The macrocytosis, according to this author, was so definite that the persistence of macrocytes was used successfully as an indication for whole blood transfusions. During the acute stages reticulocytosis was not seen.

The anemia found in association with tuberculosis is generally mild and occurs in about 20 per cent of the cases $(10,11)$. It was found to be macrocytic in 12 per cent of the cases, normocytic in 56 per cent and microcytic in 32 per cent (11). In two-thirds of the macrocytic anemias, the mean corpuscular hemoglobin was reduced below normal and in several of these macrocytosis was associated with massive reticulocytosis following hemorrhage. In 102 cases with anemia only 2 instances of macrocytosis were found, and in both of these cases the anemia was relieved by therapy (10). These may have been cases of pernicious anemia.

The anemia associated with brucellosis has been reported as macrocytic and hyperchromic (12), though the conclusions are not in accord with the data presented. The anemia was only slightly macrocytic in the female group (M.C.V. 95 c. $\mu$.) and the mean corpuscular hemoglobin concentration for each sex was in the normal range. A later report (13) indicates that in brucellosis the hemoglobin and red cell count are usually reduced proportionately, and that the anemia rarely resembles pernicious anemia.

\section{Bone marrow}

The bone marrow in cases of anemia due to infection has been studied very little. That a hyperplasia of the leukocytic elements exists is recognized, but little has been written concerning the erythroid series. The bone marrow in 11 cases of acute infection was found to be normal in 2 and hyperplastic in 9 (7). In 4 cases of chronic infection, hyperplasia of both the white and red cell series was found in all. Neutrophils and myelocytes predominated in the myeloid series, and normoblasts and "primary erythroblasts" predominated the the red cell series, suggesting a maturation arrest at this level. In 73 cases of tuberculosis with anemia the femoral marrow was hyperplastic in 61.6 per cent (11). The reaction involved mainly the myeloid series. "The qualitative shift of the erythrocytes to younger levels was comparatively slight; the change was primarily quantitative and late erythroblasts and normoblasts predominated." A marked shift toward immature red cell forms was never observed in the bone marrow.

\section{Studies on blood destruction}

It has been appropriately stated (14), "Accurate studies of hemoglobin metabolism in chronic infectious anemias have not been reported." However, what evidence is available indicates that the anemia associated with infection is not due to increased blood destruction (7). Serum bilirubin determinations have been found to be within normal limits $(7,15)$. Urobilinogen excretion was measured quantitatively in 10 cases of anemia associated with chronic infection and found normal in 9 cases and moderately increased in only 1 case (15). Similar results have been reported by others (16 to 20), all of whom used less precise methods than those now available.

Normal urobilinogen excretion has been re- 
ported in a case of chronic infectious arthritis with anemia (14).

\section{- Blood volume}

Because the total blood volume was reduced in soldiers with chronic sepsis, it was concluded that the actual deficiency of total circulating hemoglobin is in large part hidden $(8,21)$. Since the basis of comparison was not given, and it is known that "normal" total blood volume is not yet well defined and certainly varies over a wide range, these conclusions require substantiation. With reference to convalescent patients and those with chronic wound infections it has been stated (22) that when the blood volume is evaluated in terms of the individual's normal body weight the reduction in blood volume "may be of the order of 60 to 70 per cent." It was stated further that, "the hematocrit value and the plasma protein concentration may remain essentially normal and give no indication of the large deficiency in blood volume." In this article no data were presented in support of these statements.

\section{Porphyrin metabolism}

Data concerning porphyrin metabolism are extremely limited. Coproporphyrin excretion was determined in 3 individuals and an increased excretion of both coproporphyrin I and III was found (15). This was thought to be evidence suggesting a disturbed synthesis of hemoglobin.

\section{Iron metabolism}

Serum iron has been reported by several European investigators as being distinctly lowered below the normal value in acute and chronic infections $(20,23,24$ to 27$)$. Massive oral and combined oral and intravenous iron therapy were found to be ineffective in elevating the serum iron and relieving the anemia (25). Iron balance studies in children led to the conclusion that iron retention is increased in febrile states (26). The production of a mild infection or sensitization against heterologous serum or tetanus toxin in mice (28 to 30 ) was associated with accumulation of iron in the liver, spleen, and bone marrow. These authors suggested that the reticulo-endothelial system, stimulated by infection, tends to accumulate iron.
In "secondary anemia" accompanying malignancy, it has been found that there is a large accumulation of iron as well as copper in the liver, spleen, and stomach $(31,32)$.

\section{Treatment}

All authors are agreed that iron and liver therapy are without effect in this type of anemia $(8,9$, 25). Whole blood transfusions are of value in restoring the blood to normal and in one study it was reported (8) that a reticulocytosis follows whole blood transfusions. It was even concluded that products derived from whole blood stimulate erythropoiesis. Following transfusion therapy the rate of red cell regeneration was found to exceed the rate of hemoglobin synthesis.

\section{TECHNICAL PROCEDURES}

The hematological methods used were those described by Wintrobe (9). Reticulocyte counts were done by the wet preparation method. Examinations of the bone marrow were made by sternal puncture, and the smears stained with Wright's stain.

For the determination of plasma bilirubin, the method of Malloy and Evelyn (33) was used. Plasma iron was measured according to the procedure of Kitzes, Elvehjem and Schuette (34). The method of Grinstein and Watson (35) was followed for the determination of erythrocyte protoporphyrin.2 Urinary coproporphyrin determinations were made by the colorimetric method of Cartwright, Jones, Lauritsen and Wintrobe (36). The procedure for obtaining the $\mathrm{HCl}$ extract from urine is essentially that of Dobriner and Rhoads (37). The final $\mathrm{HCl}$ extract was read on the Evelyn photoelectric colorimeter using the No. 400 filter. An average of 3 consecutive 24-hour urine collections was taken on each individual. 8 Serum copper determinations were made by the method of Cartwright, Jones and Wintrobe (38). This method is based on a triple hot trichloroacetic acid precipitation and extraction of serum, following which copper is determined colorimetrically from the aqueous filtrate on the Evelyn photoelectric colorimeter using sodium diethyldithiocarbamate. Total plasma proteins were determined by the biuret method of Kingsley (39).

The study has been limited to adult male patients. The range of normal for each procedure used has been established on normal healthy adult males.

${ }^{2}$ We are indebted to Dr. C. J. Watson for supplying pure protoporphyrin.

$3 \mathrm{We}$ are indebted to Dr. K. Dobriner of the Memorial Hospital, New York and to Dr. H. Mason of the Mayo Clinic for supplying pure coproporphyrin for a standard curve. 
OBSERVATIONS

\section{Morphological characteristics of the anemia}

The morphological characteristics of the blood in 16 cases of anemia accompanying infection are summarized in Table I. Many determinations were made on each individual. The table shows a representative determination for each patient. The anemia was mild or moderate in degree. In several cases, however, the true severity of the anemia could not be appreciated because of previous transfusions. In all instances, it was either normocytic in type or moderately microcytic. The mean corpuscular hemoglobin concentration was usually normal or low normal, but in several instances it was definitely below normal. Analysis of our data suggests that the anemia is first normocytic and normochromic, and as the duration of the anemia increases, the cells may become smaller in size and the concentration of hemoglobin may diminish, provided the patient does not receive whole blood transfusions. Several of the patients with diseases of long duration listed in Table I had been transfused frequently. T. G., W. B. and T. M. received no transfusions.

In no case was the anemia macrocytic. Daily reticulocyte counts were done. The average values are shown in the table. In no case was there an increase in reticulocytes above normal.

\section{Bone marrow}

In all cases studied there was an increase in the ratio of myeloid (leukocytic) cells to nucleated red blood cells from the normal of 3-4 to 1 to 5-9 to 1. Myelocytes, metamyelocytes, and polymorphonuclear neutrophils predominated in the myeloid series. In the red cell series, polychromatic and orthochromatic normoblasts predominated. Megaloblasts were not observed, and pronormoblasts were not increased. It is to be noted that the increase in the proportion of myeloid cells in the marrow does not indicate a reduction in the red series; in fact, there may well have been an absolute increase in the number of nucleated red blood cells, but this is difficult to determine by sternal puncture.

\section{Chemical studies}

The results of measurements of plasma iron, serum copper, erythrocyte protoporphyrin, urinary coproporphyrin, plasma bilirubin, and total plasma protein in 19 cases of infection of 1 to 36 months' duration are summarized in Table II. The values given represent an average of many determinations on each individual.

\section{Iron metabolism}

It will be observed that the plasma iron content was markedly diminished in all of these cases.

TABLE I

Summary of the morphological characteristics of the blood in cases of anemia associated with infection

\begin{tabular}{|c|c|c|c|c|c|c|c|c|c|c|}
\hline Patient & Age & Condition & Duration & $\mathbf{R B C}$ & Hgb. & $\underset{\text { crit }}{\text { Hemato- }}$ & MCV* & MCH† & MCHC & Retics \\
\hline $\begin{array}{l}\text { F. M. } \\
\text { K. J. } \\
\text { F. T. } \\
\text { J. B. } \\
\text { D. S. } \\
\text { T. G. } \\
\text { W. B. } \\
\text { F. L. } \\
\text { P. F. } \\
\text { J. W. } \\
\text { S. D. } \\
\text { O. K. } \\
\text { H. B. } \\
\text { W. V. } \\
\text { T. M. } \\
\text { A. B. }\end{array}$ & $\begin{array}{l}\text { years } \\
\\
76 \\
53 \\
53 \\
83 \\
16 \\
38 \\
23 \\
31 \\
50 \\
27 \\
44 \\
65 \\
25 \\
67 \\
53 \\
52\end{array}$ & $\begin{array}{l}\text { Normal } \\
\text { Empyema } \\
\text { Osteomyelitis } \\
\text { Empyema } \\
\text { Empyema } \\
\text { Empyema } \\
\text { Osteomyelitis } \\
\text { Endocarditis } \\
\text { Pyelonephritis } \\
\text { Septicemia } \\
\text { Endocarditis } \\
\text { Empyema } \\
\text { Cellulitis } \\
\text { Tuberculosis } \\
\text { Pneumonia } \\
\text { Lung abscess } \\
\text { Pneumonia }\end{array}$ & $\begin{array}{c}\text { months } \\
\\
2 \\
2 \\
1 \\
1 \\
1 \\
36 \\
2 \\
2 \\
1 \\
6 \\
6 \\
2 \\
2 \\
1 \\
8 \\
1\end{array}$ & $\begin{array}{l}\times 10 \\
5.4 \pm 0.8 \\
4.02 \\
4.57 \\
4.36 \\
3.96 \\
4.50 \\
4.94 \\
3.91 \\
3.43 \\
3.46 \\
4.51 \\
4.16 \\
4.14 \\
4.55 \\
4.05 \\
3.63 \\
4.43\end{array}$ & $\begin{array}{c}\text { grams per } \\
\text { cent } \\
16 \pm 2 \\
11.6 \\
11.2 \\
11.6 \\
11.2 \\
12.3 \\
8.3 \\
9.3 \\
9.4 \\
10.5 \\
12.0 \\
11.5 \\
10.0 \\
11.4 \\
11.8 \\
9.6 \\
10.3\end{array}$ & $\begin{array}{c}\text { ml. per } \\
100 \text { ml. } \\
47 \pm 5 \\
35.2 \\
36.5 \\
36.4 \\
35.2 \\
36.2 \\
33.0 \\
30.0 \\
28.7 \\
32.0 \\
40.0 \\
34.0 \\
36.2 \\
39.0 \\
36.5 \\
29.0 \\
36.5\end{array}$ & $\begin{array}{c}c \mu \\
87 \pm 5 \\
87 \\
80 \\
83 \\
89 \\
80 \\
67 \\
77 \\
84 \\
92 \\
87 \\
82 \\
87 \\
86 \\
89 \\
80 \\
82\end{array}$ & $\begin{array}{c}\gamma \gamma \\
29 \pm 2 \\
29 \\
25 \\
27 \\
28 \\
27 \\
17 \\
24 \\
27 \\
30 \\
27 \\
30 \\
24 \\
25 \\
29 \\
26 \\
23\end{array}$ & $\begin{array}{c}\text { per cent } \\
34 \pm 2 \\
32 \\
31 \\
32 \\
32 \\
34 \\
25 \\
31 \\
33 \\
33 \\
30 \\
34 \\
28 \\
29 \\
32 \\
32 \\
28\end{array}$ & $\begin{array}{c}\text { per cent } \\
1 \pm 0.5 \\
1.8 \\
0.7 \\
0.8 \\
0.2 \\
0.6 \\
1.2 \\
1.3 \\
3.0 \\
1.1 \\
2.0 \\
0.4 \\
1.1 \\
0.4 \\
0.8 \\
1.6 \\
0.7\end{array}$ \\
\hline
\end{tabular}

* Mean corpuscular volume.

† Mean corpuscular hemoglobin. 
HYPOFERREMIA, HYPERCUPREMIA, AND PORPHYRIN METABOLISM

TABLE II

Chemical characteristics of the anemia of infection

\begin{tabular}{|c|c|c|c|c|c|c|c|c|c|c|}
\hline Patient & Age & Condition & $\underset{\text { tion }}{\text { Dura- }}$ & $\underset{\text { crit }}{\text { Hemato- }}$ & $\begin{array}{c}\text { Plasma } \\
\text { iron }\end{array}$ & $\begin{array}{l}\text { Serum } \\
\text { copper }\end{array}$ & $\begin{array}{l}\text { Erythro- } \\
\text { cyte } \\
\text { proto- } \\
\text { porphyrin }\end{array}$ & $\begin{array}{c}\text { Urinary } \\
\text { copro- } \\
\text { porphyrin }\end{array}$ & $\underset{\text { bilirubin }}{\text { Plasma }}$ & $\begin{array}{c}\text { Total } \\
\text { plasma } \\
\text { proteins }\end{array}$ \\
\hline $\begin{array}{l}\text { F. M. } \\
\text { E. M. } \\
\text { S. D. } \\
\text { J. T. } \\
\text { K. J. } \\
\text { F. T. } \\
\text { J. B. } \\
\text { D. S. } \\
\text { T. G. } \\
\text { W. B. } \\
\text { F. L. } \\
\text { P. F. } \\
\text { O. K. } \\
\text { R. T. } \\
\text { T. M. } \\
\text { A. B. } \\
\text { S. B. } \\
\text { H. B. } \\
\text { W. V. }\end{array}$ & $\begin{array}{l}\text { years } \\
76 \\
48 \\
44 \\
60 \\
53 \\
53 \\
83 \\
16 \\
38 \\
23 \\
31 \\
50 \\
65 \\
16 \\
53 \\
52 \\
52 \\
25 \\
67\end{array}$ & $\begin{array}{l}\text { Normal } \\
\text { Empyema } \\
\text { Empyema } \\
\text { Cellulitis foot } \\
\text { Scrotal abscess } \\
\text { Osteomyelitis } \\
\text { Empyema } \\
\text { Empyema } \\
\text { Empyema } \\
\text { Osteomyelitis } \\
\text { Endocarditis } \\
\text { Pyelonephritis } \\
\text { Septicemia } \\
\text { Cellulitis } \\
\text { Osteomyelitis } \\
\text { Lung abscess } \\
\text { Pneumonia } \\
\text { Osteomyelitis } \\
\text { Tuberculosis } \\
\text { Pneumonia }\end{array}$ & $\begin{array}{r}\text { months } \\
\\
2 \\
24 \\
3 \\
1 \\
2 \\
1 \\
1 \\
1 \\
36 \\
2 \\
2 \\
1 \\
2 \\
16 \\
8 \\
1 \\
36 \\
2 \\
1\end{array}$ & 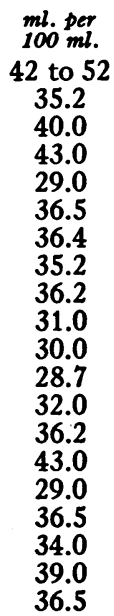 & $\begin{array}{c}\gamma \text { per cent } \\
90 \text { to } 150 \\
27 \\
38 \\
34 \\
38 \\
31 \\
25 \\
29 \\
23 \\
16 \\
25 \\
28 \\
35 \\
35 \\
25 \\
30 \\
25 \\
30 \\
28 \\
40\end{array}$ & $\begin{array}{l}220 \\
\\
230 \\
\\
210 \\
258 \\
146 \\
246 \\
228 \\
174 \\
262 \\
246 \\
202\end{array}$ & $\begin{array}{c}\gamma \text { per } 100 \\
m l . R B C \\
20 \text { to } 50 \\
42 \\
145 \\
180 \\
108 \\
213 \\
97 \\
116 \\
78 \\
634 \\
171 \\
259 \\
106 \\
218 \\
95 \\
446 \\
91 \\
58 \\
67 \\
210\end{array}$ & $\begin{array}{l}192 \\
440 \\
355 \\
208 \\
300 \\
352 \\
230 \\
178 \\
190 \\
145 \\
550 \\
253 \\
228\end{array}$ & 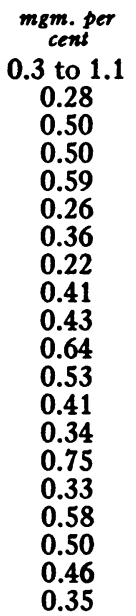 & 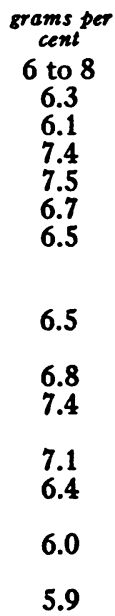 \\
\hline
\end{tabular}

The normal range for humans by the method used, as determined on 20 normal healthy young males, was $120 \pm 30$ micrograms per cent. In the above cases, the values ranged between 15 and 40 micrograms per cent.

In order to determine the speed with which hypoferremia develops in infections, measurements were made in several cases of acute infection. In a case of meningococcal meningitis, the plasma iron was 57 micrograms per cent 24 hours after the onset of the infection. In a case of pneumococcal meningitis, the plasma iron was found to be 29 micrograms per cent on the second day of the illness. Similar changes were observed in a case of erysipelas and in 4 cases of pneumonia, 2 of the "atypical" variety and 2 pneumococcal in origin. The plasma iron in these cases ranged from 23 to 64 micrograms per cent. None of these patients developed anemia. In Figure 1 the course of 1 patient with uncomplicated lobar pneumonia involving the left lower lobe is presented. The patient entered the hospital on the fifth day of illness. At this time, the plasma iron level was 131 micrograms per cent. The infection was promptly relieved with sulfadiazine, and by the ninth day of illness (fourth hospital day), the patient was afebrile and asymptomatic. On the tenth day of illness, the plasma iron was 32 micrograms per cent. Nine days later, the plasma iron had risen to 95 micrograms per cent. Anemia did not develop, and there was no rise in erythrocyte protoporphyrin.

We have not studied a sufficient number of patients with acute infections to be able to state the frequency of hypoferremia in infections. As indicated above, in severe illnesses, the plasma iron may fall to abnormally low levels within several days of the onset. In 1 case of pneumonia (W. V.), there was an initial hemolytic phase with an elevated plasma bilirubin and hyperferremia; hypoferremia did not develop until the twenty-first day of the illness. From the limited number of observations made to date, it would appear that the hypoferremia precedes the development of anemia, if anemia develops at all. This is illustrated by the course of W.B. (Figure 2). In 4 cases of chronic tuberculosis without anemia, the plasma iron values were found to be $51,50,42$, and 36 micrograms per cent.

Two hundred and thirty observations in 6 cases of chronic infection over periods of 4 to 6 months indicate that hypoferremia remains as long as the infection persists. In cases in which anemia was present, the blood counts and clinical condition of the patients were restored to normal long before the plasma iron reached the normal range. 


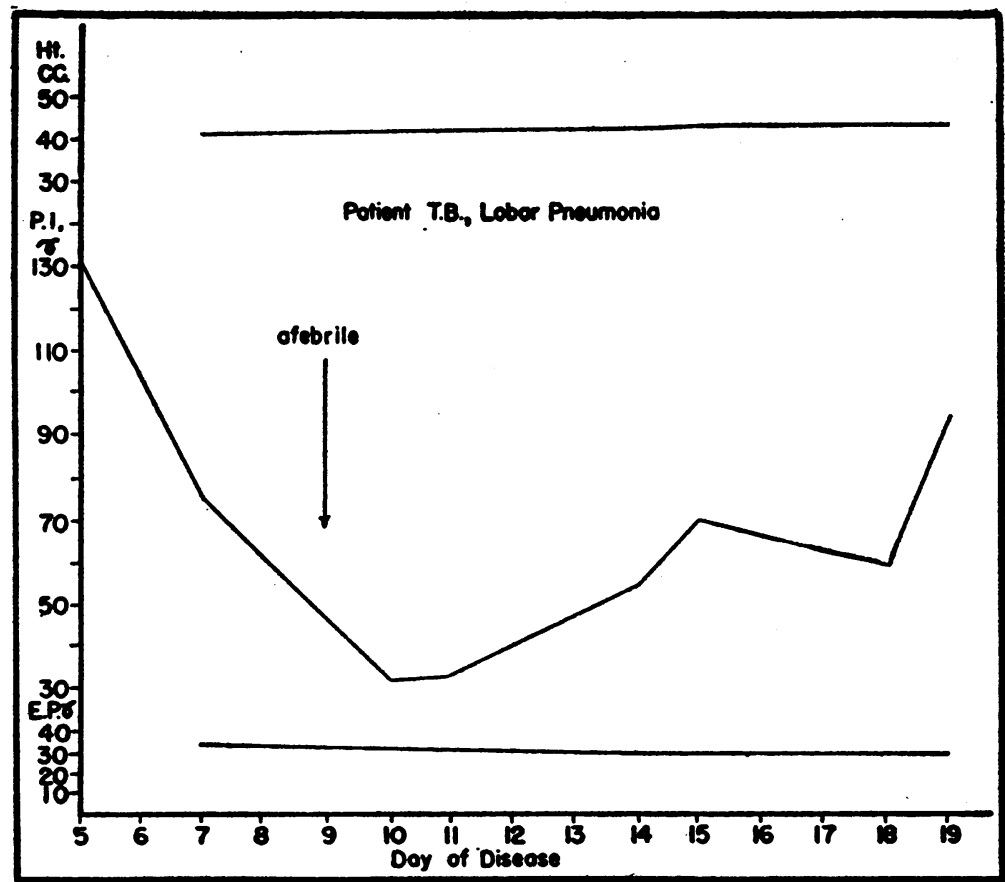

Fig. 1. Changes in Plasma iron (P. I.) in a Patient, T. B., Age 62, with Uncomplicated Lobar Pneumonia (Left Lower Lobe) Treated Successfully with Sulfadiazine

No changes occurred in erythrocyte protoporphyrin (E. P.) and anemia did not develop (Ht. refers to volume of packed red cells).

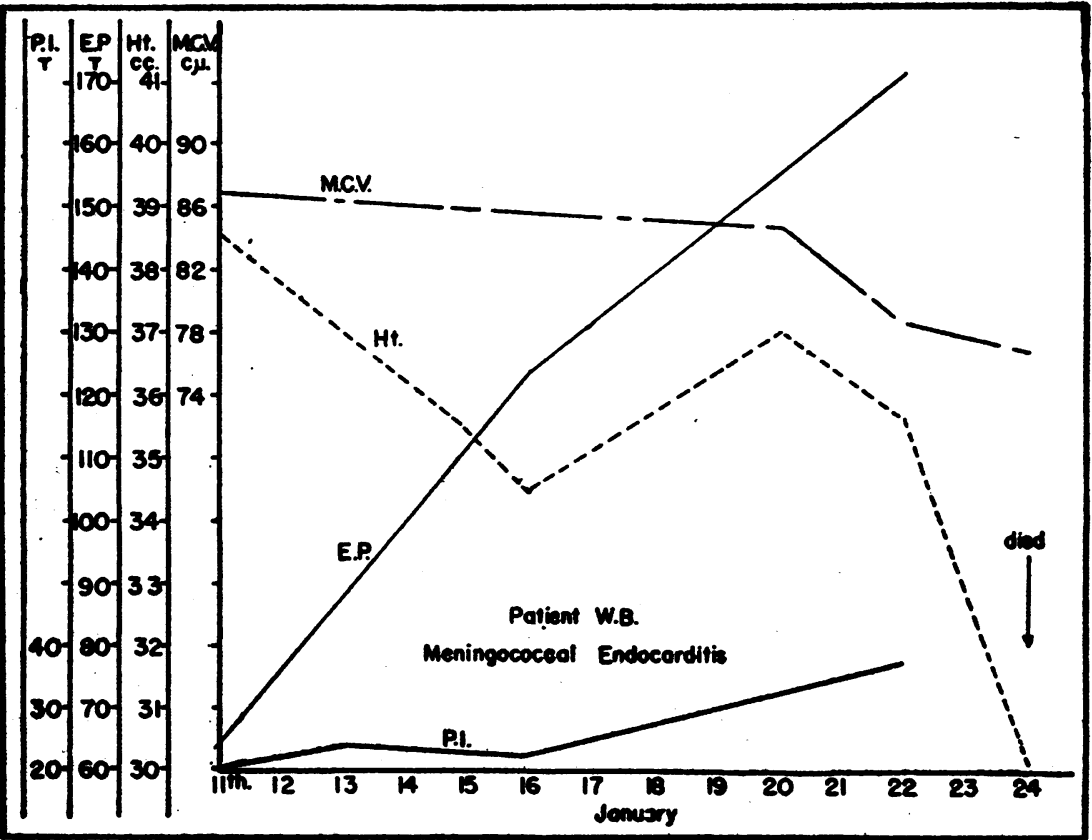

Fig. 2. Changers in Plasma Iron Content (P. I.) and in Epythrocyte Protoporphyrin (E. P.) and the Developient of Anemia (Ht. Rerers to Volume of Packé Rej Cinls) and Slight Microcytosis (MCV Rerers to Mran Corpuscular Volume) in a Case of Meningococcal Endocarditis

The hypoferremia was present before anemia began to develop. The erythrocyte protoporphyrin increased as anemia progressed. 
The plasma iron level following administration of 1 gram of ferrous sulfate by mouth was studied in a number of cases, as well as the changes which occurred following intravenous administration of $0.5 \mathrm{mgm}$. of iron ascorbate per pound of body weight. The results of these studies are illustrated in Figures 3 and 4 . Whereas in normal controls, the plasma iron content increased even almost threefold in 2 to 4 hours following oral administration of ferrous sulfate, in the cases of anemia associated with infection, the plasma iron level was essentially unchanged.

Following the intravenous administration of iron, there was a rapid rise in the plasma iron level in normal individuals, as well as in the patients. In the latter, however, the initial 5-minute rise was not as great as in the controls and the iron disappeared from the blood stream much more rapidly. The plasma iron in the anemic individuals returned to the pre-injection levels in approximately 4 hours, whereas in the normal subjects the pre-injection level was not reached until after 9 hours. The flat oral absorption curves would suggest, at first glance, faulty absorption of iron in the anemia associated with infection. The rapid disappearance of iron from the blood stream following intravenous injection of iron in these cases indicates, however, that the flat curves following oral administration may be attributable to the rapid removal of iron.

In order to compare the manner in which these patients handle iron with the manner in which patients with iron deficiency utilize this element, plasma iron levels following oral and after intravenous administration of iron were determined in a male patient with marked hypochromic microcytic anemia due to iron deficiency. It is well recognized that patients with iron deficiency anemia absorb iron at an accelerated rate (40 to 42) but the increase in plasma iron following its ingestion may be insignificant or quite pronounced (40). In the case of iron deficiency anemia in which the studies illustrated in Figures 5 and 6 were made, the results corresponded with those

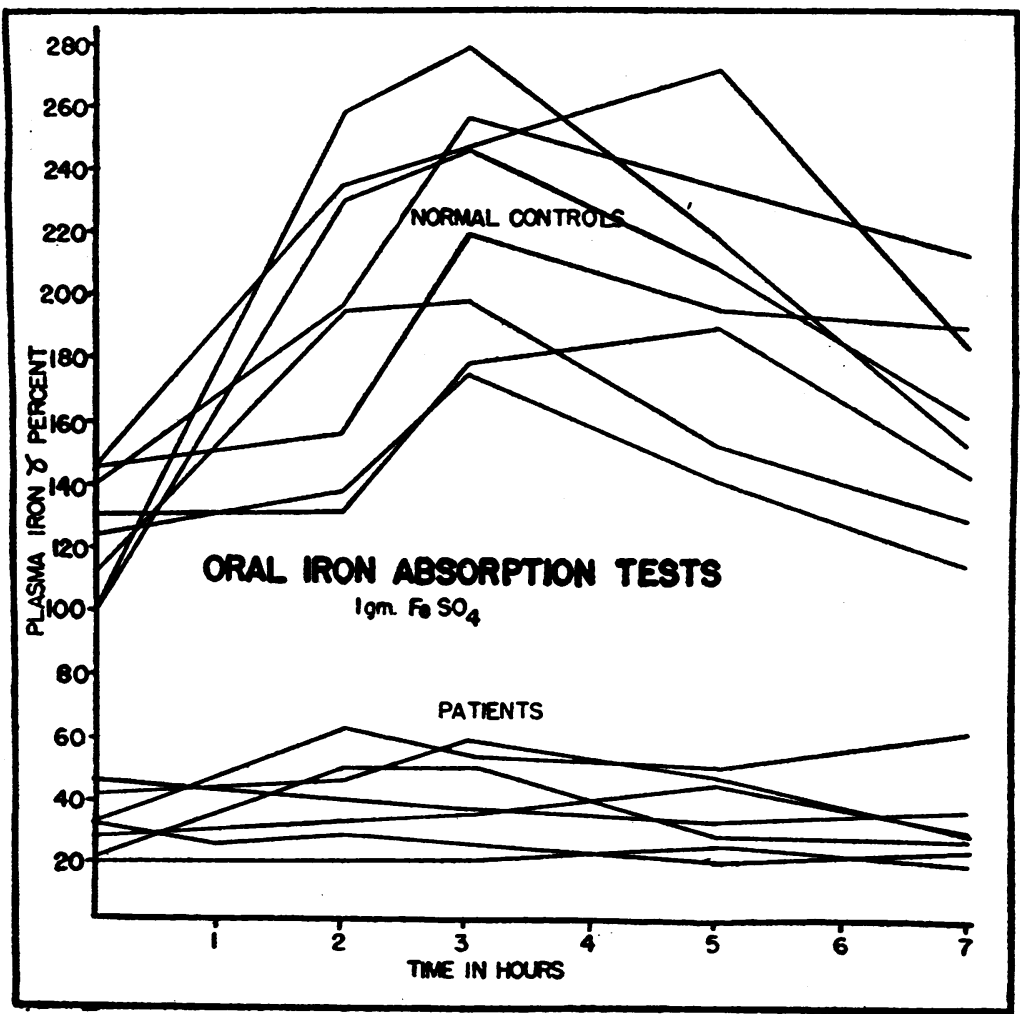

Fig. 3. The Plasma Iron Level in 7 Patients with Chronic Infections AND in 8 Norkal. Indtviduals Following the Ingestion of 1 Gram Ferrous Sulfate 


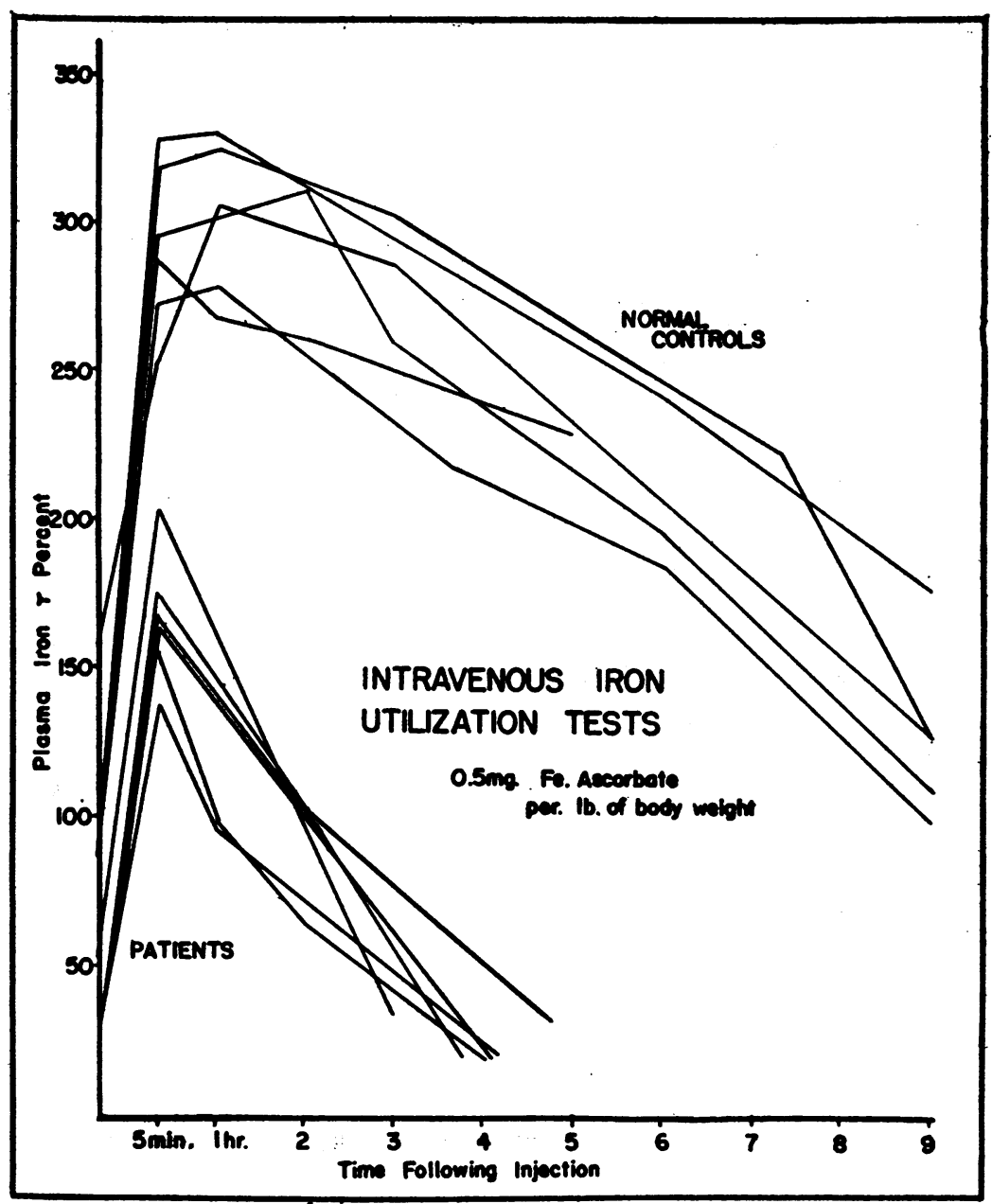

Fig. 4. The Plasma Iron Levei in 7 Patients with Chronic Infections and in 6 Normal Individuals Following the Intravenous Administration of 0.5 Mgm. Iron Ascorbate per Pound of Body Weight

found in cases of anemia associated with infection. In both types of anemia, the oral iron absorption curve was flat and iron injected intravenously disappeared rapidly.

\section{Copper}

The serum copper was found to be elevated in all of the cases studied. The normal range for serum copper, as determined in 25 healthy young males, was $116 \pm 20$ micrograms per cent (38). The values in the patients, with 2 exceptions, ranged from 200 to 262 micrograms per cent.

Copper determinations were not carried out throughout the course of the infections, and we are unable to state how soon or how rapidly a rise in serum copper occurs, nor can we indicate the rate at which it returns to normal.

\section{Porphyrin metabolism}

The erythrocyte protoporphyrin was elevated in all of the cases studied, with one exception (F. M.). The normal range for this determination, as measured by us in 10 normal young males, was 20 to 50 micrograms per $100 \mathrm{ml}$. of red blood cells. This corresponds well with the values previously obtained by the same method (43). In the patients listed in Table II, the values for erythrocyte protoporphyrin were increased 2 to 14 times above normal.

We have been unable, in the limited number of 
cases studied, to correlate the degree of rise in erythrocyte protoporphyrin with the nature, severity, or duration of the infection, or with the character or severity of the anemia. The rise in erythrocyte protoporphyrin in the 10 cases in which measurements were made throughout their courses, developed somewhat later than the fall in plasma iron and returned to normal more slowly. An increase in erythrocyte protoporphyrin was not observed in cases of acute infection with hypoferremia (see Figure 1). It was seen only in the somewhat more chronic or severe cases of anemia and usually returned to the normal range only after the patient had made full clinical recovery and the plasma iron level had returned to normal. Considerably more information is needed concerning the rate of development of changes in erythrocyte porphyrin.

Urinary coproporphyrin excretion was also increased above the normal values in all of the patients studied. The average 24 hour excretion for 22 normal healthy young males by this method was 106 micrograms. The range extended from 40 to 150 micrograms. This value corresponds well with that obtained by others using similar methods $(37,44,45)$. It should be pointed out, however, that colorimetric and spectroscopic methods give somewhat higher results than fluorometric methods (46). In order to ascertain that the substance measured by this method was actually coproporphyrin, determinations in many cases were made both fluorometrically and colorimetrically on the same specimen, and it was found that the coproporphyrin excretion was increased as determined by either method. Absorption spectra obtained on a Beckman quartz spectrophotometer correspond to curves obtained with pure coproporphyrin. Coproporphyrin determinations were made only at the height of the anemia.

Plasma bilirubin values were either within the normal range or slightly diminished in all of the cases. The total plasma proteins were within the normal range in all instances. In the 6 cases in which the A/G ratio was measured, it was found to be normal.

In Figure 2, the course of 1 patient is presented. This patient (W. B.), age 23, developed meningococcemia 6 weeks prior to admission and endo-

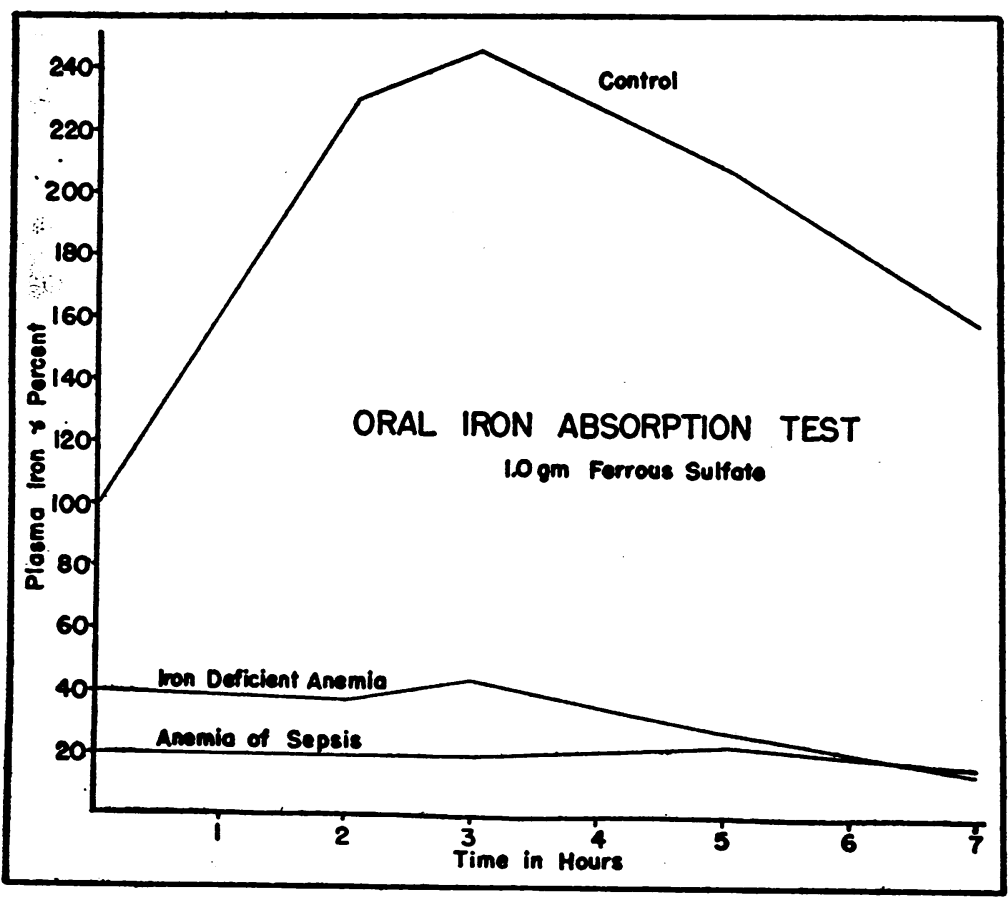

Fig. 5. Comparison of Plasma Iron levels in a Patient with Iron Defictency Anemia following the Ingestion of 1 Gram Ferrous Sulfate with the Plasma Iron levels in a Case of Chronic Infection and a Normal Individual under Similar Conditions 


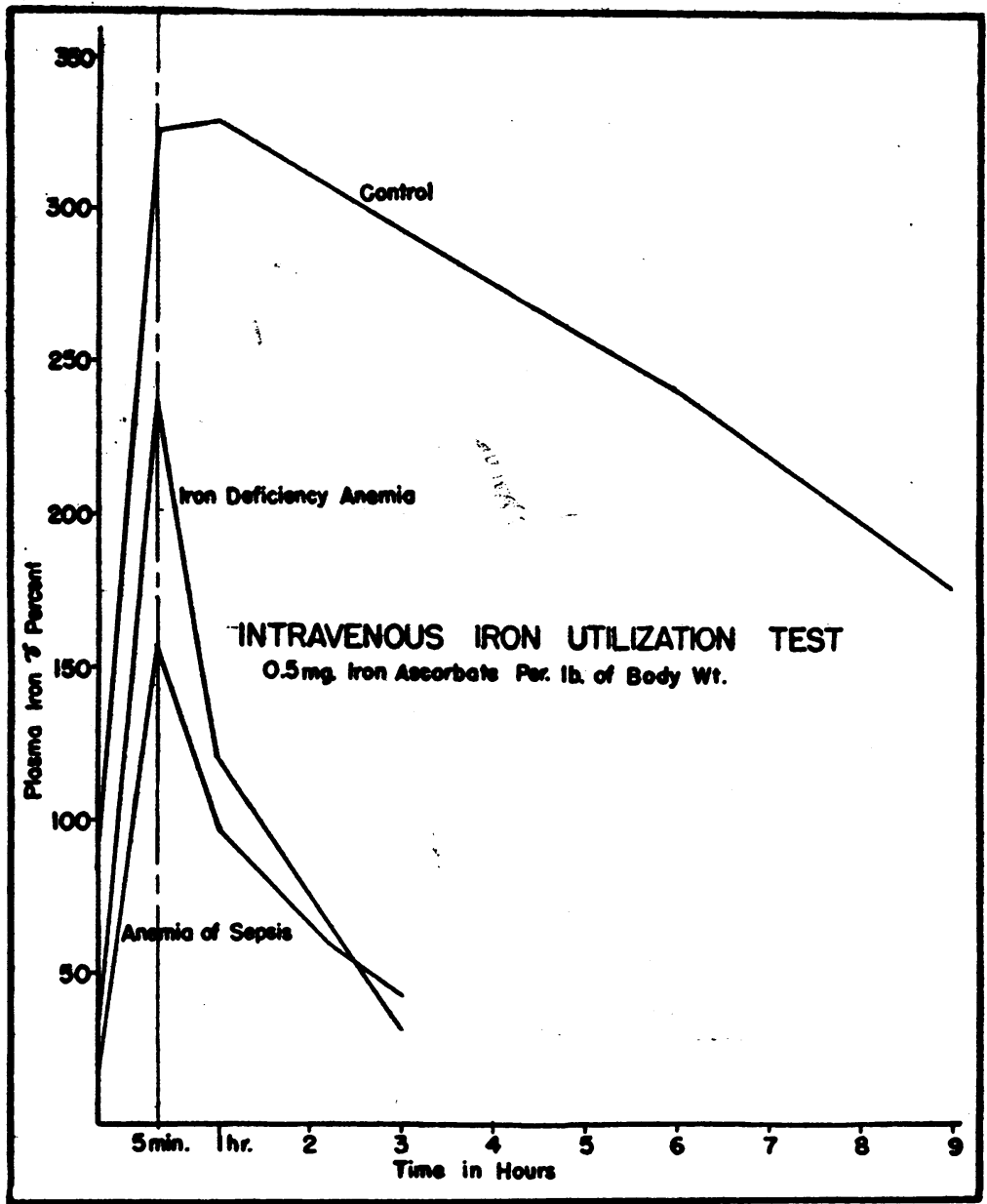

Fig. 6. Comparison of Plasma Iron Levels in a Patient with Iron Deficiency Anemia Following the Intravenous Injection of 0.5 Mgm. Iron Ascorbate per Pound of Body Weight, with the Plasma Iron Levels in a Case of Chronic Infection and in a Normal Individual under Similar Conditions

carditis 4 weeks before admission. During his hospital stay, his course was progressively downward, and death occurred 13 days following admission. During this time, the volume of packed red cells fell from 38.4 to $30.0 \mathrm{ml}$., the mean corpuscular volume diminished 10 c. $\mu$., and the erythrocyte protoporphyrin rose from 64 micrograms to 171 micrograms per $100 \mathrm{ml}$. of red blood cells. On admission, the plasma iron was at the extremely low level of 20 micrograms per cent and remained at approximately this level. The small variations in plasma iron are not significant. It is noteworthy that the plasma iron was at an extremely low level before significant anemia, microcytosis, or increase in erythrocyte protoporphyrin developed. Serum copper determinations were not made on this patient. The urinary coproporphyrin excretion averaged 230 micrograms per 24 hours.

\section{TREATMENT OF THE ANEMIA}

The results of attempts to alleviate the anemia in the cases of infection are summarized in Table III. The iron ascorbate was injected slowly intravenously as a 1 per cent solution. The insoluble globin powder was prepared according to the procedure of Anson and Mirsky (47). Reticulocyte counts were made daily during the assay periods. 
Both F. T. and R. T. had previously received transfusions which resulted in a rise in volume of packed red cells to normal. In spite of this, the hypoferremia persisted and was not affected by either oral or intravenous administration of iron. R. T. received a total of 1.5 grams of iron ascorbate, the equivalent of 0.33 gram of iron, intravenously over a 30 -day period without effect on the plasma iron level. T. G. received ferrous sulfate orally for $\mathbf{4 0}$ days in addition to copper sulfate orally for 20 days and $100 \mathrm{mgm}$. of iron ascorbate intravenously daily for 20 days without effect on the plasma iron level, volume of packed red cells, or erythrocyte protoporphyrin, in spite of the fact that his anemia was microcytic and even hypochromic. The administration of 6 members of the vitamin B complex plus ascorbic acid, given in conjuction with iron therapy in one case (R. T.), was ineffective.

The failure of penicillin to relieve the anemia in the 2 cases in which it was used was associated with the failure of the penicillin to alleviate the infection in these 2 cases of chronic osteomyelitis. The ineffectiveness of globin, "amigen," cystine, and methionine in 1 patient (T. G.) suggests that the anemia is probably not due to a primary protein deficiency. Neither did copper sulfate nor a crude extract of liver seem to be of any therapeutic value.

The results following whole blood transfusions

TABLE III

The effect of the administration of various therapeutic agents in cases of anemia associated with infection

\begin{tabular}{|c|c|c|c|c|c|c|c|c|c|}
\hline Patient & \multicolumn{2}{|c|}{ Therapy } & Dose & $\begin{array}{l}\text { Route of } \\
\text { adminis- } \\
\text { tration* }\end{array}$ & Number & Hematocrit & $\begin{array}{c}\text { Maximal } \\
\text { reticulocyte } \\
\text { response }\end{array}$ & $\underset{\text { iron }}{\text { Plasma }}$ & $\begin{array}{l}\text { Erythrocyte } \\
\text { proto- } \\
\text { porphyrin }\end{array}$ \\
\hline \multirow{4}{*}{ F. T. } & \multirow{2}{*}{\multicolumn{2}{|c|}{ Iron ascorbate }} & \multirow[t]{2}{*}{$\begin{array}{c}\text { daily } \\
50 \text { mgm. }\end{array}$} & \multirow{2}{*}{ i.v. } & $\begin{array}{c}\text { days } \\
0\end{array}$ & $\begin{array}{c}m l . \text { per } \\
100 \mathrm{ml} . \\
41\end{array}$ & \multirow{2}{*}{$\begin{array}{c}\text { per cent } \\
0.8\end{array}$} & $\begin{array}{c}\gamma \text { per cent } \\
19\end{array}$ & $\begin{array}{c}\gamma \text { per } 100 \mathrm{ml} . \\
R B C \\
97\end{array}$ \\
\hline & & & & & 10 & 40 & & 27 & 80 \\
\hline & \multirow{2}{*}{\multicolumn{2}{|c|}{ Ferrous sulfate }} & \multirow{2}{*}{0.8 gram } & \multirow{2}{*}{ o } & 0 & 34 & \multirow{2}{*}{3.2} & 15 & 540 \\
\hline & & & & & 10 & 34 & & 16 & 730 \\
\hline \multirow{4}{*}{ T. G. } & \multirow{2}{*}{\multicolumn{2}{|c|}{ Ferrous sulfate }} & \multirow{2}{*}{1.2 grams } & \multirow{2}{*}{0} & 10 & 34 & \multirow{2}{*}{3.0} & 16 & 730 \\
\hline & & & & & 20 & 34 & & 22 & 666 \\
\hline & \multirow{2}{*}{\multicolumn{2}{|c|}{$\begin{array}{l}\text { Ferrous sulfate } \\
\text { Iron ascorbate } \\
\text { Copper sulfate }\end{array}$}} & \multirow{2}{*}{$\begin{array}{c}1.2 \text { grams } \\
100 \mathrm{mgm} . \\
64 \mathrm{mgm} .\end{array}$} & \multirow{2}{*}{$\begin{array}{c}\text { o } \\
\text { i.v. } \\
0\end{array}$} & 20 & 34 & \multirow{2}{*}{1.6} & 22 & 666 \\
\hline & & & & & 40 & 36 & & 18 & 548 \\
\hline \multirow{2}{*}{ R. T. } & \multirow{2}{*}{\multicolumn{2}{|c|}{$\begin{array}{l}\text { Iron ascorbate } \\
\text { Vitamin B complex }\end{array}$}} & \multirow{2}{*}{$\begin{array}{c}50 \text { mgm. } \\
t\end{array}$} & \multirow{2}{*}{$\begin{array}{l}\text { i.v. } \\
0\end{array}$} & 0 & 45 & \multirow{2}{*}{2.0} & 19 & 80 \\
\hline & & & & & 30 & 46 & & 27 & 87 \\
\hline \multirow{2}{*}{ S. B. } & \multirow{2}{*}{\multicolumn{2}{|c|}{ Penicillin }} & \multirow{2}{*}{$\begin{array}{c}240,000 \\
\text { units }\end{array}$} & \multirow{2}{*}{ i.m. } & 0 & 36 & \multirow{2}{*}{3.5} & 35 & \\
\hline & & & & & 16 & 24 & & 40 & \\
\hline \multirow{2}{*}{ T. G. } & \multirow{2}{*}{\multicolumn{2}{|c|}{ Penicillin }} & \multirow{2}{*}{$\begin{array}{c}360,000 \\
\text { units }\end{array}$} & \multirow{2}{*}{ i.m. } & 0 & 29 & \multirow{2}{*}{1.4} & 16 & 489 \\
\hline & & & & & 10 & 29 & & 19 & 496 \\
\hline \multirow[t]{2}{*}{ T. G. } & Amigen & 5 days & $1000 \mathrm{ml}$. & i.v. & 0 & 34 & 20 & 15 & 427 \\
\hline & Methionine & 12 days & 6 grams & $\mathbf{0}$ & 12 & 33 & 2.0 & 18 & 489 \\
\hline$T r$ & Crude extra & & 50 & 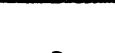 & 0 & 36 & & 18 & 548 \\
\hline & liver (Wil & on) & Jo gians & 0 & 12 & 34 & 1.4 & 15 & 427 \\
\hline
\end{tabular}

* i.v. indicates intravenous administration, o oral and i.m. intramuscular.

† Thiamin hydrochloride, $25 \mathrm{mgm}$.; riboflavin, $25 \mathrm{mgm}$.; nicotinamide, $100 \mathrm{mgm}$.; pyridoxine hydrochloride, 50 mgm.; calcium pantothenate, 50 mgm.; paraaminobenzoic acid, 100 mgm.; ascorbic acid, $100 \mathrm{mgm}$.

† Mead Johnson and Company. 
TABLE IV

The effect of whole blood transfusions on the anemia of infection

\begin{tabular}{|c|c|c|c|c|c|c|c|}
\hline Patient & Period & Hematocrit & $\underset{\text { iron }}{\text { Plasma }}$ & $\begin{array}{l}\text { Erythrocyte } \\
\text { proto- } \\
\text { porphyrin }\end{array}$ & $\begin{array}{c}\text { Reticulocyte } \\
\text { increase }\end{array}$ & $\underset{\substack{\text { Hematocrit } \\
\text { increase }}}{ }$ & $\begin{array}{c}\text { Erythrocyte } \\
\text { proto- } \\
\text { porphyrin } \\
\text { decrease }\end{array}$ \\
\hline \multirow{2}{*}{ F. T. } & Initial & $\begin{array}{c}m l . \text { per } 100 \mathrm{ml} \text {. } \\
48\end{array}$ & $\begin{array}{c}\gamma \text { per cent } \\
50\end{array}$ & $\begin{array}{c}\gamma \text { per } 100 \mathrm{ml} . \\
R B C \\
83\end{array}$ & \multirow{2}{*}{0} & per cent & per cent \\
\hline & $500 \mathrm{ml}$. W.B. & 53 & 58 & 66 & & 10 & 20 \\
\hline \multirow{2}{*}{ J. B. } & Initial & 35 & 65 & 113 & \multirow{2}{*}{0} & & \\
\hline & $2000 \mathrm{ml}$. W.B. & 48 & 38 & 49 & & 37 & 57 \\
\hline \multirow{2}{*}{ T. G. } & Initial & 29 & 19 & 496 & \multirow{2}{*}{$\mathbf{0}$} & & \\
\hline & $2500 \mathrm{ml}$. W.B. & 45 & 33 & 288 & & 55 & 42 \\
\hline \multirow{2}{*}{ F.L. } & Initial & 30 & 28 & 296 & \multirow{2}{*}{0} & & \\
\hline & $1000 \mathrm{ml}$. W.B. & 40 & 45 & 211 & & 33 & 28 \\
\hline \multirow{2}{*}{ F. L. } & Initial & 32 & 33 & 199 & \multirow{2}{*}{0} & & \\
\hline & $1000 \mathrm{ml}$. W.B. & 41 & 53 & 86 & & 28 & 57 \\
\hline \multirow{2}{*}{ P. F. } & Initial & 30 & 62 & 111 & \multirow{2}{*}{0} & & . \\
\hline & $1500 \mathrm{ml}$. W.B. & 38 & 47 & 40 & & 27 & 64 \\
\hline \multirow{2}{*}{ T. M. } & Initial & 27 & 29 & 300 & \multirow{2}{*}{$\mathbf{0}$} & & \\
\hline & $2500 \mathrm{ml}$. W.B. & 38 & 25 & 107 & & 41 & 64 \\
\hline
\end{tabular}

W.B. refers to whole blood.

are presented in Table IV. The transfusions were associated with a rise in the volume of packed red cells, and the clinical condition of the patients improved. Such transfusions failed, however, to affect the hypoferremia. During and shortly following transfusions, there was a temporary elevation in plasma iron probably due to hemolysis, but following this the iron rapidly returned to its previous low level. The erythrocyte protoporphyrin decreased following the transfusions. In cases in which the infection persisted, the protoporphyrin returned to its previously high level in 2 to 6 weeks. The fall in erythrocyte protoporphyrin, however, was greater in 5 of the 7 cases than the degree of increase in volume of packed red cells. Whether transfusions have a specific effect on the amount of porphyrin in the erythrocytes other than that caused by mixture of the patient's red cells with those of the donor we are unable to state conclusively.

In general, the results of attempts at therapy thus far would seem to indicate that until the infection is relieved, it is not possible to modify the metabolic defects found in the hematopoietic system.

\section{DISCUSSION}

The data which have been presented indicate that in cases of infection associated with anemia the plasma iron content is markedly lowered below the normal, the serum copper is elevated, the erythrocyte protoporphyrin is greatly raised, and the excretion of coproporphyrin is increased. Administration of iron by mouth is associated with no significant increase in the content of iron in the plasma, in sharp contrast to the findings in normal persons. Intravenous administration of iron is associated with a rise in the plasma iron level which is somewhat less than in the normal, and there is a much more rapid return to pre-injection levels. In these respects, the plasma iron changes correspond to those observed in iron deficiency anemia. The data suggest that absorption of iron may be adequate, and that iron is being removed rapidly from the plasma. Unlike what occurs in iron deficiency anemia, iron therapy, 
even intravenously, does not influence the anemia associated with chronic infection.

On the basis of preliminary observations, it appears that the hypoferremia develops very early in association with infection and seems to precede the development of anemia. If the infection is promptly relieved, the plasma iron may return rapidly to normal, and no anemia develops. Hypoferremia has been observed to persist as long as the infection remained and may lag behind the hemoglobin rise which takes place during recovery. The rise in erythrocyte protoporphyrin seems to occur more gradually as anemia develops. This porphyrin has been shown (43) to be protoporphyrin type III, number 9 , the porphyrin from which heme is synthesized. The time relationships of the rise in serum copper to the fall in plasma iron and the increase in erythrocyte protoporphyrin have not yet been determined.

A hypothetical scheme of the formation and destruction of hemoglobin is outlined in Table V. Anemia presumably may develop (a) as a result of deficient blood formation represented in reaction 1 to 4 ; or $(b)$ as the consequence of increased blood destruction, represented in reaction 5 . In the anemia associated with infection no evidence has been found of increased blood destruction as measured quantitatively by urobilinogen excretion (15 to 20). In 1 patient (J. B.) studied by us, the urobilinogen excretion was actually diminished, averaging only $37 \mathrm{mgm}$. per day. Furthermore, the plasma bilirubin in the patients in this study was not elevated. It would seem that the anemia must develop as a result of deficient blood formation. Thus reaction 4 , representing the ultimate formation of hemoglobin, is inadequate.

\section{TABLE V \\ Formation and destruction of hemoglobin}

1. Porphyrin precursors $\rightarrow$ Protoporphyrin type III No. 9

2. Protoporphyrin + Iron $\stackrel{\mathrm{Cu}++}{\longrightarrow}$ Heme

3. Amino acids $\rightarrow$ globin

4. Heme + Globin $\rightarrow$ Hemoglobin

5. Hemoglobin $\rightarrow$ Verdohemochromogen $\rightarrow$ Bile pigments

Considering the possible location of the defect in the chain of hemoglobin synthesis, it can be stated that reaction 1 is probably not at fault since protoporphyrin is present in the erythrocytes, even in excess. The evidence against defective globin

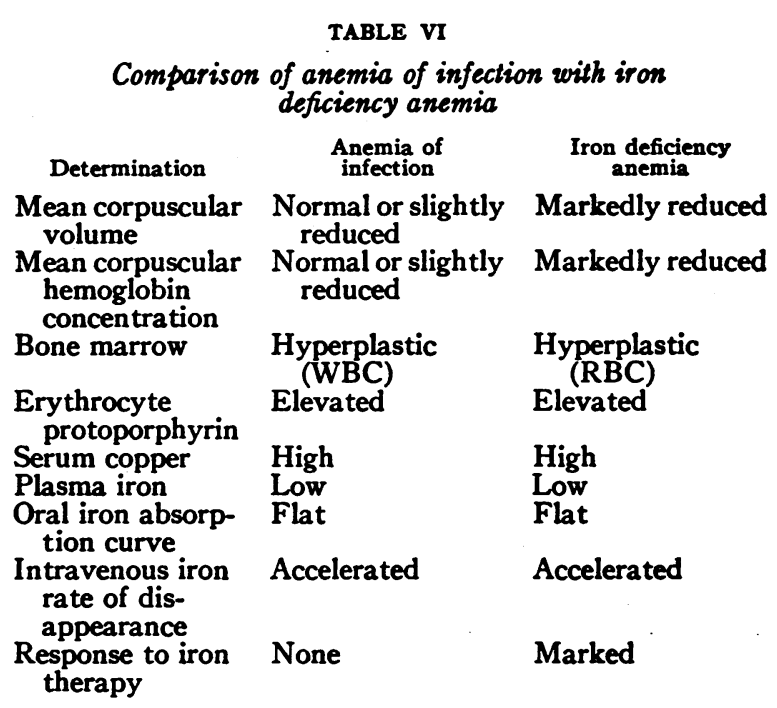

formation (reaction 3) is that in the patients studied the total plasma protein levels were normal. It has been concluded (48) that when protein is not supplied in adequate amounts, the body draws first on the plasma proteins and only later on hemoglobin. Additional evidence is offered in the observations on T. G. who, when supplied with globin, amigen, methionine, and cystine, failed to respond. Nevertheless, it must be kept in mind that a negative nitrogen balance does develop in the presence of infection (49), and a fault in protein metabolism may in some way be related to the anemia under discussion.

The present evidence would suggest that reaction 2 is at fault ; that is, there is deficient formation of heme. The increase in the urinary excretion of coproporphyrin is compatible with this. It is now generally agreed that coproporphyrinuria does not indicate increased hemoglobin breakdown, but represents a failure at some stage in the synthesis of heme $(53,54)$.

Our observations indicate that both protoporphyrin and copper are present in increased amounts, and the plasma iron is markedly diminished. There are several reasons to suggest that there is a "deficiency" of iron, and that the protoporphyrin and the copper are increased awaiting the time when iron will be made available so that the formation of heme may proceed at its normal rate.

The anemia of infection corresponds to the anemia of iron deficiency in many respects. These are summarized in Table VI. Hypercupremia and 
an elevated erythrocyte protoporphyrin have been shown to occur in iron deficiency $(43,50$ to 52$)$. In both the anemia of infection and in iron deficiency anemia, the bone marrow is hyperplastic. In both conditions, the plasma iron is low, the curve for plasma iron following the ingestion of iron may be flat, and iron injected into the blood stream disappears more rapidly than is normal.

That the anemia of infection is not due to a primary deficiency of iron as a result of diminished intake or reduced absorption is indicated by the fact that ( $a$ ) the anemia develops more rapidly than could be explained on the basis of cessation of absorption of iron; $(b)$ the microcytosis and hypochromia are neither as consistent nor as marked as in primary deficiency; and (c) the anemia of infection fails to respond to either the oral or intravenous administration of iron.

These observations all indicate that there must be in association with infection a derangement in the intermediate metabolism of iron which diverts the element to some other location and deprives the hemopoietic tissues of iron. It has been shown that iron, once absorbed, is not excreted (55 to 59). Consequently, if adequate amounts of iron are reaching the blood stream, it would appear that iron is being diverted from hemoglobin formation by important demands elsewhere. These must be in the tissues.

Evidence is available to suggest that inflammatory tissue has a peculiar affinity for iron. Thus it has been shown $(60,61)$ both by tissue staining and by chemical analysis that following the injection of iron into rabbits, there is an accumulation and fixation of iron in inflammatory tissue and in tuberculous areas in the lungs. An accumulation of iron in the reticuloendothelial system occurs in mice given mild injections, and the administration of parenteral iron under such conditions leads to an increase in tissue iron, but not to an increase in hemoglobin (28).

By the use of radioactive iron, it should be possible to determine whether or not iron absorption is normal, or even increased, in the presence of infection, and to discover where the iron which is absorbed passes. If iron is adequately absorbed but is deviated from hemoglobin synthesis, as we have postulated, it will be important to determine what function such a diversion plays. It might be expected that this function is an important one since it takes precedence over so fundamental a process as hemoglobin formation. The experimental production of hypoferremia is described in the paper which follows.

\section{SUM MARY}

1. The anemia associated with infection is usually normocytic and normochromic but may become slightly microcytic and slightly hypochromic. No accompanying reticulocytosis has been observed.

2. The bone marrow is hyperplastic, and there is an increase in the myeloid-erythroid ratio.

3. Hypoferremia, hypercupremia, an increase in the amount of protoporphyrin contained in the red cells, and coproporphyrinuria have been observed, but plasma bilirubin and total plasma proteins have been found normal.

4. There is a pronounced alteration in iron metabolism, as indicated by hypoferremia, flat oral iron absorption curves, and rapid disappearance of iron from the blood stream following intravenous injection.

5. The anemia of infection corresponds to the anemia of iron deficiency in certain respects but does not respond to iron therapy.

6. Copper, the vitamin B complex, ascorbic acid, "amigen," globin, cystine, methionine and crude liver failed to correct the anemia.

7. Whole blood transfusions were associated with alleviation of the anemia and improvement in the well-being of the patients but failed to correct the underlying disturbances in iron and porphyrin metabolism.

8. The theory is offered and evidence is presented that the anemia of infection is due to failure to form heme as the result of a lack of iron to incorporate into the protoporphyrin molecule. This "lack" may be due to an abnormality in the intermediate metabolism of iron which diverts this metal to the tissues and makes it unavailable for hemoglobin synthesis.

\section{BIBLIOGRAPHY}

1. Pepper, O. H. P., Hematology of subacute Streptococcus viridans endocarditis. J.A.M.A., 1927, 89, 1377.

2. Collins, D. H., Observations on anemia in chronic rheumatic diseases. Lancet, 1935, 2, 548.

3. Hubbard, J. P., and McKee, M. H., The anemia of rheumatic fever. J. Pediat., 1939, 14, 66. 
4. Rasmussen, H., Norsk. Mag. Laegevidensk, 1936, 97, 1113 , cited in Saif, M. F., and Vaughan, J. M., reference 7.

5. Josephs, H. W., Anemia of infancy and early childhood. Medicine, 1936, 15, 307.

6. Wintrobe, M. M., Anemia. Arch. Int. Med., 1934, 54, 256.

7. Saifi, M. F., and Vaughan, J. M., The anemia associated with infection. J. Path. \& Bact., 1944, 56, 189.

8. Lyons, C., Unpublished observations.

9. Wintrobe, M. M., Clinical Hematology. Lea and Febiger, Philadelphia, 1942, p. 404.

10. Braverman, M. M., Anemia of pulmonary tuberculosis. Am. Rev. Tuberc., 1938, 38, 466.

11. Muller, G. L., Clinical Significance of the Blood in Tuberculosis. Commonwealth Fund, New York, 1943, p. 11.

12. Calder, R. M., Steen, C., and Baker, L., Blood studies in brucellosis. J.A.M.A., 1939, 112, 1893.

13. Harris, H. J., Brucellosis, Undulant Fever: Clinical and Subclinical. Paul Hoeber, Inc., New York, 1941, 2nd Ed., p. 118.

14. Watson, C. J., The pyrrol pigments. Handbook of Hematology. Paul Hoeber, Inc., New York, 1938, IV, 2545.

15. Vaughan, J. M., and Saif, M. F., Hemoglobin metabolism in chronic infections. J. Path. \& Bact., 1939, 49, 69.

16. Eppinger, H., and Charnas, D., Was lehren uns quantitative Urobilinbestimmungen im Stuhl? Ztschr. f. klin. Med., 1913, 78, 387.

17. Bauman, L., Chemistry and clinical significance of urobilin. Arch. Int. Med., 1921, 28, 475.

18. Weiss, M., Uber Urobilin und seine diagnostische Verwertung. Wien. Arch. f. inn. Med., 1930, 20, 39.

19. Paschkis, K., Blutmauserung und Urobilinstoff wechsel. Ergebn. d. inn. Med. u. Kinderh., 1933, 45, 682.

20. Heilmeyer, L., and Plötner, K, Das Serumeisen und die Eisenmangelkrankheit. Jena: Fischer. 1937.

21. Lyons, C., Penicillin therapy of surgical infections in the U. S. Army; report. J.A.M.A., 1943, 123, 1007.

22. Gregersen, M. I., A practical method for the determination of blood volume with the dye T-1824. J. Lab. \& Clin. Med., 1944, 29, 1266.

23. Brochner-Mortensen, K., and Stein, K. S., The serum iron content in patients with acute and chronic infectious diseases. Nord. Med., 1942, 13, 235. In Chem. Abst., 1944, 38, 5571.

24. Thoenes, F., and Aschaffenburg, R., Iron metabolism in growing organisms. A literary, clinical and experimental study. Jahrb. f. Kinderheilk., 1934, 141, 1. In Chem. Abst., 1935, 29, 5168.

25. Schäfer, K. H., Zur Pathogenese der Infektanämie, insbesondere ihre Beziehungen zum Eisenstoffwechsel des wachsenden Organismus. Klin. Wchnschr., 1940, 19, 590.
26. Schäfer, K. H., Untersuchungen über den exogenen Eisenstoff wechsel bie fieberhaften Infekten im Kindesalter. Klin. Wchnschr., 1940, 19, 979.

27. Hirvonen, M., The iron content of serum in some ordinary infections. Acta med. Scandinav., 1941, 106, 495. In Chem. Abst., 1941, 35, 4467.

28. Schäfer, K. H., Gewebeeisenstoff wechsel und Hämoglobinbildung bei Infektionen. Klin. Wchnschr., 1943, 22, 98.

29. Schäfer, K. H., The influence of infections and similar processes on the iron metabolism. Z. ges. exptl. Med., 1942, 110, 678, 697. In Chem. Abst., 1944, 38, 2384.

30. Volland, W., The intermediary iron metabolism after repeated injection of foreign serum. Klin. Wchnschr., 1940, 19, 1242. In Chem. Abst., 1943, 37, 675.

31. Sandberg, M., Gross, H., and Holly, O. M., Changes in retention of copper and iron in liver and spleen in chronic diseases accompanied by secondary anemia. Arch. Path., 1942, 33, 834.

32. Gross, H., Sandberg, M., and Holly, O. M., Changes in copper and iron retention in chronic diseases accompanied by secondary anemia; changes in liver, spleen and stomach. Am. J. M. Sc., 1942, 204, 201.

33. Malloy, H. T., and Evelyn, K. A., Determination of bilirubin. J. Biol. Chem., 1937, 119, 481.

34. Kitzes, G., Elvehjem, C. A., and Schuette, H. A., The determination of blood plasma iron. J. Biol. Chem., 1944, 155, 653.

35. Grinstein, M., and Watson, C. J., Studies of protoporphyrin; photoelectric and fluorophotometric methods for quantitative determination of protoporphyrin in blood. J. Biol. Chem., 1943, 147, 675.

36. Cartwright, G. E., Jones, P. J., Lauritsen, M. A., and Wintrobe, M. M., Coproporphyrin determination in urine. To be published.

37. Dobriner, K., and Rhoads, C. P., The quantitative determination of urinary coproporphyrin. New England J. Med., 1938, 219, 1027.

38. Cartwright, G. E., Jones, P. J., and Wintrobe, M. M., The determination of copper in blood serum. J. Biol. Chem., 1945, 160, 593.

39. Kingsley, G. R., Determination of serum total protein, albumin, and globulin by the biuret reaction. J. Biol. Chem., 1939, 131, 197.

40. Moore, C. V., Arrowsmith, Wm. R., Welch, J., and Minnich, V., Studies in iron transportation and metabolism; observations on the absorption of iron from the gastro-intestinal tract. J. Clin. Invest., 1939, 18, 553.

41. Hahn, P. F., Bale, W. F., Lawrence, E. O., and Whipple, G. H., Radioactive iron and its metabolism in anemia. Its absorption, transportation and utilization. J. Exper. Med., 1939, 69, 739.

42. Balfour, W. M., Hahn, P. F., Bale, W. F., Rommerenke, W. T., and Whipple, G. H., Radioactive iron absorption in clinical conditions; normal, pregnancy, anemia, and hemochromatosis. J. Exper. Med., 1942, 76, 15. 
43. Watson, C. J., Grinstein, M., and Hawkinson, V., Studies of protoporphyrin; a comparison of erythrocyte protoporphyrin concentration with reticulocyte percentage under experimental and clinical conditions. J. Clin. Invest., 1944, 23, 69.

44. Rosenblum, L. A., and Jolliffe, N., Porphyrinuria in pellagra. Am. J. M. Sc., 1940, 199, 853.

45. Dobriner, K., Strain, W. H., and Localio, S. A., I. Quantitative measurement of coproporphyrin and total coproporphyrin I excretion in normals. Proc. Soc. Exper. Biol. \& Med., 1937, 36, 752.

46. Dobriner, K., and Rhoads, C. P., Porphyrins in health and disease. Physiol. Rev., 1940, 20, 416.

47. Anson, M. L., and Mirsky, A. E., Protein coagulation and its reversal. The preparation of insoluble globin, soluble globin, and heme. J. Gen. Physiol., 1929, 13, 469.

48. Whipple, G. H., Hemoglobin and plasma proteins; their production, utilization and interrelation. Am. J. M. Sc., 1942, 203, 477.

49. Howard, J. E., Protein metabolism during convalescence after trauma. Arch. Surg., 1945, 50, 166.

50. Sachs, A., Levine, V. E., and Fabian, A. A., Copper and iron in human blood. Arch. Int. Med., 1935, 55, 277.

51. Sachs, A., Effect of bleeding ulcers and hemorrhagic anemia upon whole blood copper and iron. Amer. J. Digest. Dis. \& Nutrition, 1938, 4, 803.

52. Sachs, A., Levine, V. E., and Griffith, W. O., Proc. Soc. Exper. Biol. \& Med., 1936, 35, 6.
53. Rimington, $C$., An enzymatic theory of haemopoiesis. Compt. rend. d. trav. du lab. Carlsberg, Carlsberg Laboratory, Copenhagen, 1938, 22, 454.

54. Dobriner, K., Strain, W. H., Localio, S. A., Keutmann, H., and Stephens, D. I., II. Coproporphyrin I. Metabolism and hematopoietic activity. Proc. Soc. Exper. Biol. \& Med., 1937, 36, 755.

55. Greenberg, D. M., Coppe, D. H., and Cuthbertson, E. M., Studies in mineral metabolism with aid of artificial radioactive isotopes; distribution and excretion, particularly by way of bile, of iron, cobalt and manganese. J. Biol. Chem., 1943, 147, 749.

56. Hahn, P. F., Bale, W. F., Hettig, R. H., Kamen, M. O., and Whipple, G. H., Radioactive iron and its excretion in urine, bile, and feces. J. Exper. Med., 1939, 70, 443.

57. Hawkins, W. B., and Hahn, P. F., Biliary excretion of radioactive iron and total iron as influenced by red cell destruction. J. Exper. Med., 1944, 80, 31.

58. McCance, R. A., and Widdowson, E. M., Iron excretion and metabolism in man. Nature, London, 1943, 152, 326.

59. Maddock, S., and Heath, C. W., Is iron excreted by gastrointestinal tract of dog? Histologic study, Arch. Int. Med., 1939, 63, 584.

60. Menkin, V., Studies on inflammation; fixation of metal in inflamed areas. J. Exper. Med., 1930, $51,879$.

61. Menkin, V., and Menkin, M. F., The accumulation of iron in tuberculous areas. J. Exper. Med., 1931, 53, 919. 